\title{
Lithuanian Emigrants' Approach to National Security: Case Study
}

\author{
Rolanda KAZLAUSKAITE் MARKELIENE் ${ }^{1}$, Mindaugas GVILDYS ${ }^{2}$ \\ 1,2 General Jonas Žemaitis Military Academy of Lithuania, Department of Humanities, Šilo str. 5A, 10322 Vilnius, \\ Lithuania
}

E-mail: ${ }^{1}$ rolanda.kazlauskaite@lka.lt

\begin{abstract}
Increasing emigration leads to the loss of investments in human capital as well as to the constraint of the knowledge economy via a huge leakage of demographical and intellectual capacity, hence threatening national security, social and economic stability. The target of the article is to examine the Lithuanian emigrants' attitudes toward national security by analysing the relationship between emigration and national security, by disclosing the reasons for emigration, and by investigating the emigrants' stance on national security. Long-term emigration lasting longer than a year has a greater impact on the country since most of long-term emigrants do not return. This is confirmed by the data revealing that most of emigrants live abroad for ten years or longer. Short-term (for less than a year) emigration can be qualified as a search for temporary financial improvement. It becomes evident amid financial crisis during which the loss of job opportunities and emigration leads to an increase in search for personal income and new experience abroad. Ninetyfour percent of participants of this research identify themselves as long-term emigrants, and $76 \%$ of them have a higher education. It points to the loss of educational investment and qualified labour force. The research reveals that most of survey respondents do not expect to return, for they do not trust the authorities. In addition, they deem that it is not reasonable to increase funding for the Lithuanian Armed Forces. The results of the study allow conclusions to be drawn that emigration is a real threat to Lithuania's national security.
\end{abstract}

KEY WORDS: national security, public security, emigration, long-term emigration, human capital, economic stability, migratory trends

\section{Introduction}

The process of globalization has severely affected many countries in the world. Different economic development of the countries affects the growth of emigration, and Lithuania is no exception. Prior to COVID-19, the scale of emigration in Lithuania increased, and this caused a number of economic, demographic, and social problems. Population aging, emigration, and low birth rate leads to a decrease in the labor force and the shortage of qualified specialists. Emigration is considered a serious threat to the country's demographic situation, economic growth, and preservation of cultural identity. The country is called a "wandering country," and researchers observing migratory trends use the term "brain drain." All these changes presuppose examining the issues of national security through the prism of emigration.

The rate of emigration from Lithuania has exceeded 3\% and poses a serious threat to the country's national security. According to the data of the Lithuanian Department of Statistics, the number of people emigrating has been gradually decreasing in recent years, but it still remains quite high: in 2015, 44.5 thousand persons emigrated from Lithuania; in 2016, 50.3 thousand; in 2017, 57.2 thousand; and in 2018, 32.2 thousand. The population of Lithuania was less than three million (2.810 million) at the end of 2018. Prior to COVID-19, migration data per thousand people were among the highest in the EU. Over the last twenty-five years, more than 800,000 people have emigrated from Lithuania, thereby making up a quarter of the country's population.

On the one hand, long-term emigration has bigger negative ramifications for the country - the majority of emigrants do not return to Lithuania, and the country loses funds which have been invested in civic education - but on the other hand, it can be viewed as a support during the financial crisis in which there is a lack of new jobs; the emigrants' incomes are increasing; and new experiences are gained abroad. Ninety-four percent of survey respondents are in long-term emigration, and as many as $76 \%$ of them have a higher education. These research results verify a threat that emigrants will not return to Lithuania, that the country will lose funds to be invested in education, and

\footnotetext{
${ }^{1}$ Corresponding author.

E-mail address: rolanda.kazlauskaite@lka.lt
} 
that we will have no qualified specialists. The research revealed that a large part of emigrants do not plan to return to Lithuania, do not trust the main state institutions (the Seimas, the Ministry of the Interior, courts), do not see the need to allocate state funds to the Lithuanian Armed Forces, and do not believe in the benefits of reintroducing conscription. The results of the study point to the threat emigration represent to Lithuania's national security.

Emigration can be considered as one of the biggest non-military threats and challenges to the existence of the Republic of Lithuania. However, reducing or eliminating this threat is difficult, for it is hard to influence the scale of emigration, and there is no effective migration management system that would enable one to manage the determinants of migration and predict the consequences. One of the tasks of the national security strategy is to promote return migration; however, the data presented by the Lithuanian Department of Statistics show that the number of returning emigrants to Lithuania does not increase every year, which makes an assumption that encouraging return migration is not effective.

With an increasingly high level of emigration in Lithuania, one is encountered with a threat emigration poses to national security. The society is aging, and the question arises as to whether there will be enough people capable of defending their country, if necessary. The country is facing a severe demographic and intellectual decline, thus hampering the development of the knowledge economy and implying a loss of public investments in the education of these individuals.

The term of national security is widely used at various levels: academic, political, and societal. However, it is quite difficult to define the boundaries of national security. Scientific literature offers many definitions of the concept of national security. There has been a marked shift in the concept of security: national security has long been perceived as a military issue. Most researchers focused on the action-response dynamics. National security is defined as the ability of countries to preserve their independent identity and functional integrity against the forces of change they see hostile. It consists of interconnected military, political, economic, social, and ecological sectors. The emigration-driven threat to national security should be divided into two categories: the threat of immigration and that of emigration. According to Lithuanian scientists [17], since the scale of immigration in Lithuania has not been an issue thus far (28 thousand immigrants in 2018) [12], threats posed by immigration are not that significant to consider now; therefore, more attention is to be paid to the threats posed by emigration.

\section{Emigration in the Context of Lithuania's National Security}

For a long time, the concept of security has mainly been associated with international and national security, but right at the end of the 20th century one starts to pay attention to the analysis of security at the individual level. Barry Buzan's book People, States and Fears gave new impetus to rethink the concept of security [20]. Buzan distinguishes between international, national, and individual security levels (vertical dynamics of the security concept) and five main interrelated security sectors: military, political, economic, social, and environmental (horizontal dynamics of the security concept) [14]. The various definitions of the concept of national security are interconnected - that is, they all stress the ability to protect the country - and only the reasons for protection differ. B. Buzan points out that national security is all about the preservation of independent identity; M. Saward emphasizes the threat of military attack; and G. Luiciani accentuates foreign aggression [6].

According to the traditional concept of security, a state itself is considered to be the object of security. This concept is based on the idea that societal or individual interests depend on the interests of the state as an organization [7]. According to this concept, what is of overarching importance is to protect the territory of the state, the institutions, the values, and the population as a unit.

The threats posed to national security are the determinants which impede coherent development of state and society and endanger the independent state, the well-being of its citizens, their rights and freedoms. The National Security Strategy [16] states, “A decline in Lithuania's population - which is conditioned by low birth rates, aging population, and high emigration rates - represents a threat to Lithuania's long-term social, economic, and political stability and economic development. Prolonged negative demographic trends reduce Lithuania's economic potential, hinder the development of the state economy, and encumber the pursuit of sustainable economic growth and prosperity" [9]. In addition, such emigration is considered a serious threat to the country's demographic development, economic growth, and preservation of cultural identity [3], which promotes nationalization and, at the same time, increases a threat to national security. One of the priorities of national security policy is to strengthen social security and improve a demographic situation. In order to achieve the said, one is to promote return migration, ensure connections between state and foreign Lithuanians so as that they can foster the Lithuanian identity and maintain political, economic, civic, and cultural relations with the Republic of Lithuania [9].Thus, incentivizing return emigration is one of the priorities and tasks of the national security strategy.

According to the Law on the Basics of National Security of the Republic of Lithuania [10], all the threats posed to national security can be divided into external and internal ones. Most of the risks to national security are of 
continuous nature, and it is difficult to eliminate them completely. A changing geopolitical situation in Lithuania in recent years impels one to virtually review those threats which endanger the security of the Lithuanian population. Given geopolitical changes, the results of the study conducted in 2017 revealed that a sense of security is more associated with personal security, less with security within the country, lesser with the level of international security [5]. Not only does the response to external threats give confidence to the authorities, but it also strengthens solidarity and patriotism and makes one contribute personally to the country's defense [4]. The sense of security is greatly influenced by a person's personal experiences, on the basis of which he evaluates a certain situation in the immediate environment.

According to the research conducted in 2017, understanding threats differs significantly when security problems in both Lithuania and the European Union are compared. Respondents evaluated the importance of security issues [5]. Analyzing the research data, we can identify three most important security issues (see Table 1).

Table 1.

Evaluation of security issues in Lithuania and the European Union

\begin{tabular}{|c|c|c|}
\hline Security Issue & Lithuania & EU \\
\hline Emigration & 90 & 78 \\
\hline Unemployment & 90 & 85 \\
\hline Criminality & 88 & 88 \\
\hline
\end{tabular}

Source: Janušauskienė et el., 2017

The research data reveal that the most important security problems in Lithuania are internal, social, and economic ones: emigration, unemployment, crime, poor economic situation, poverty, discrimination, alcoholism, and energy security. According to the survey respondents, the European Union's problems include those related with military and political security: protection of external borders, possible military attack on any of the European Union's countries, terrorism, refugees from Asia and Africa, and possible collapse of the euro area. Lithuanian people regard external problems as important, albeit less important than internal ones. Nevertheless, their understanding of threats depends on specific political, economic, social, ecological circumstances and external threats of one period or another.

Emigration can be referred to as one of the biggest non-military threats and challenges to the survival of the Republic of Lithuania. Researchers [18] note that large-scale emigration of the population is an internal risk factor, danger, and threat to national security to which one must pay great attention in that the total and especially workingage population decreases, the number of taxpayers and qualified specialists diminishes, the emigrants' relations with their homeland weaken, the gap between emigrated citizens and political processes taking place in Lithuania grows, and the chance to actively participate in the country's political life is lost.

International migration can be long-term or short-term. Long-term migration is considered when the period of emigration is at least one year. Meanwhile, short-term international migration is defined as temporary emigration lasting from three months to one year [2]. Long-term migration has greater consequences for the country, because most emigrants do not return to Lithuania, and the country loses the funds that have been invested in civic education, thus losing qualified specialists. Hence, short-term emigration can be viewed as a support in the event of a financial collapse during which there is a lack of job opportunities; people's incomes increase; and new experiences are obtained abroad [3].

The decision to emigrate is determined by the various factors whose weight of significance to each citizen varies and changes over time. People choose to emigrate if the benefits outweigh the costs. The key determinants of emigration can be as follows: economic (wage level, economic non / growth, unemployment), sociocultural (migration "fashion," traditions, non / tolerance), political (political system, election results) [13], [8], psychological (ability to make personal decisions), security (due to military or other conflicts, political or other repression), geographical (climatic conditions), population / demographic, etc. [3]

One of the main factors influencing emigration is economic (unemployment rate, wage changes, GDP per capita). We can examine one of the factors - that is, changes in the rate of unemployment.

Figure 1 shows that there is a correlation between the number of emigrants and the changes in the unemployment rate during almost the entire selected period. In 2013-2014, the number of emigrants has dropped significantly by $6 \%$ and $5.7 \%$, respectively. With the rise in unemployment in 2015 , the number of emigrants went up sharply. In 2016, there was lower growth in unemployment and in the number of emigrants. Only in 2017 did the changes differ - the rate of unemployment rose, but the number of emigrants fell by $5 \%$. 


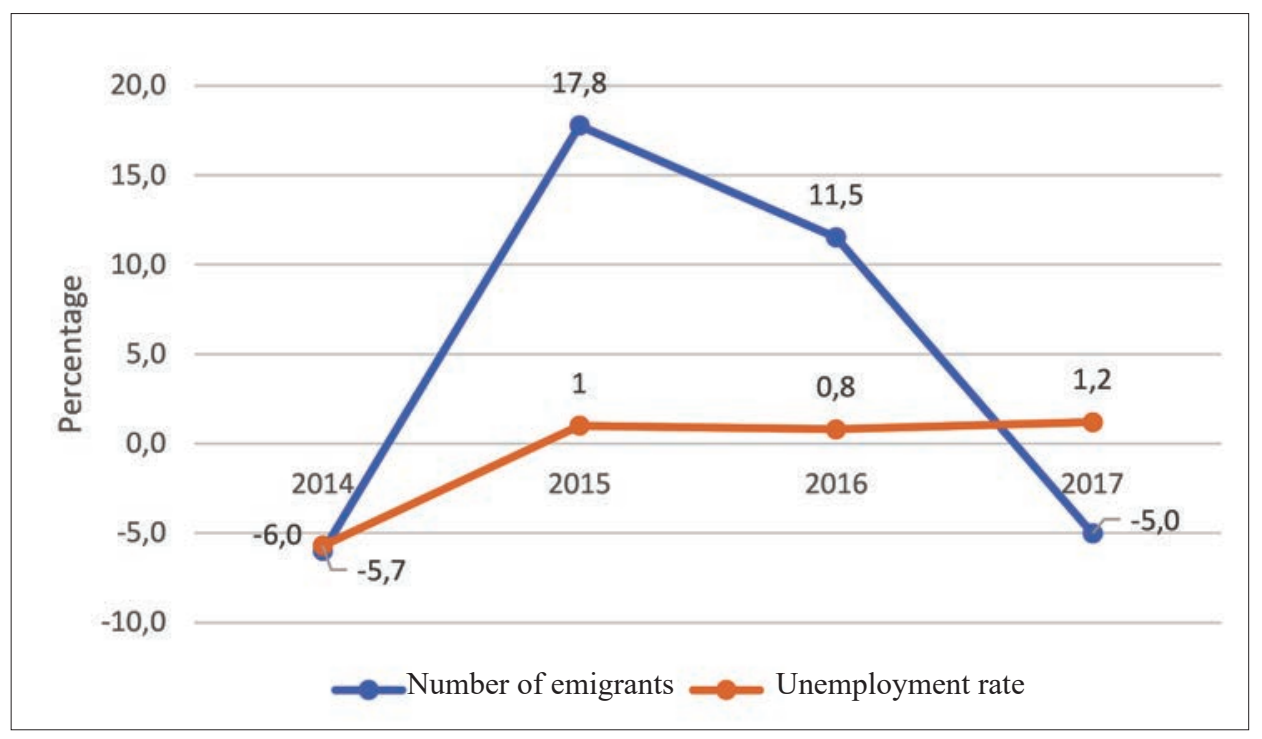

Fig 1. Changes in the number of emigrants and in the unemployment rate in the period 2014-2017.

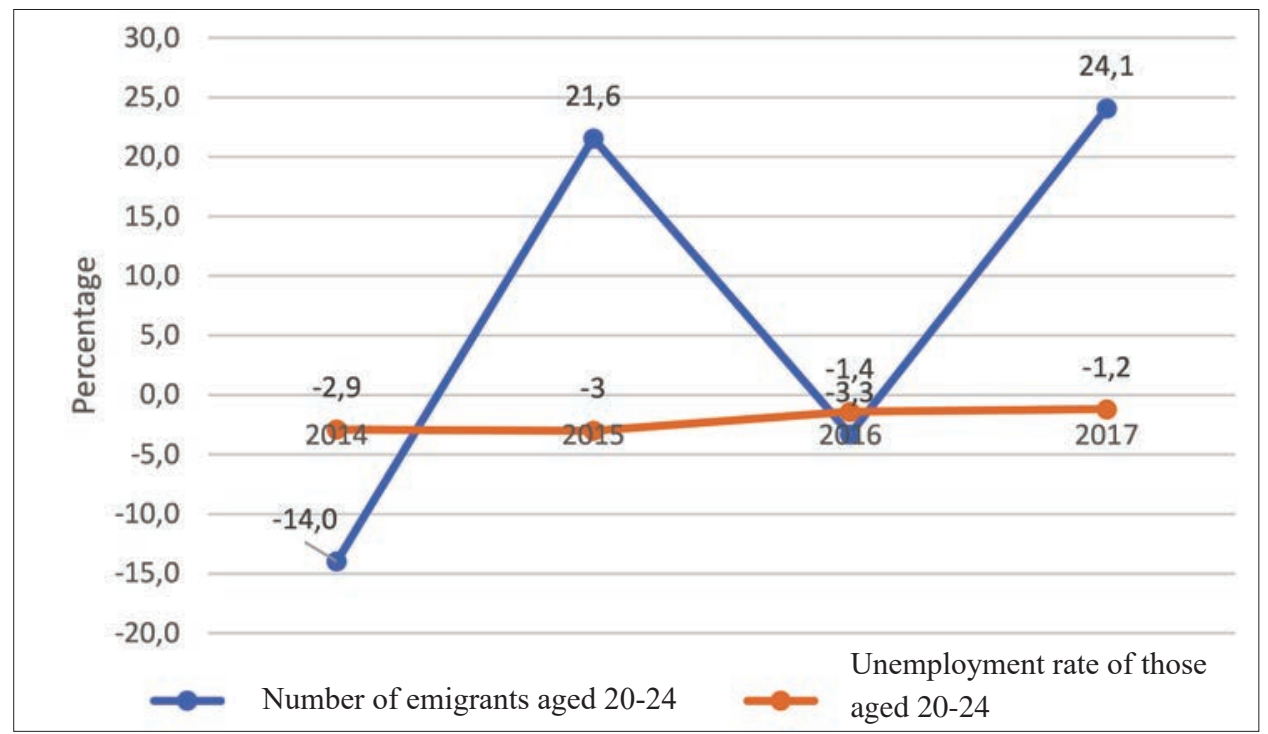

Fig 2. Changes in the number of emigrants aged 20-24 and in the unemployment rate in the period 2014-2017.

Figure 2 shows that there are no tendentious correlations between the changes in the size of emigration and in the unemployment rate among young people aged 20-24. The level of unemployed young people aged 20-24 gradually decreased every year, while the number of emigrants in the afore-mentioned age group was very volatile. It increased and then decreased regardless of the unemployment rate. This absence of dependency confirms idea that emigration often helps to resolve unemployment problems, but in today's Lithuania emigration is not always caused by unemployment. Lithuanians are very inclined to give in to fashion and fashionable living standards [1].

Provided by the data of Lithuanian Department of Statistics, the economic indicators of unemployment, GDP, and monthly wages are summarized as follows: although economic indicators, GDP per capita, monthly wages improved each year in the period 2013-2017, the number of emigrants increased nonetheless. Only in 2017, when the fastest growth of indicators was observed (GDP per capita grew by $9 \%$, monthly wages by $8.8 \%$ ), could one see a decrease in emigration by $5 \%$. The changes pertaining to the rate of unemployment, to the general population, as well as to those aged 20-24 did not affect a number of emigrants.

It is the media that forms a negative opinion of Lithuania, thereby encouraging emigration. An unfavorable emigration framework prevails in the media and is constructed by emphasizing Lithuania's economic and political problems, or the advantages of foreign countries. A recurring pattern of highlighting the negative aspects of Lithuania in the most sensitive context of poor living conditions and disadvantageous political realities altogether reveals a strong media aspiration to promote economic migration via discourse [15]. 
In summary, it can be stated that emigration can be called one of the biggest non-military threats and challenges to the survival of the Republic of Lithuania. Large-scale emigration is an internal risk factor, danger, and threat to national security to which it must be given high attention due to the declining total and especially working-age population, to the loss of taxpayers and qualified specialists, to the weakening of the emigrants' relationship with their homeland, to the disintegration of emigrated citizens from political processes occurring in Lithuania, to the inability to actively participate in a political life of the country. The decision to emigrate is determined by the various factors the weight of whose importance varies for each citizen and changes in the course of time. One chooses emigration if the benefits outweigh the costs. Emigrants must sacrifice both the costs of relocation and the psychological costs of separation from their relatives and homeland. When emigrating, citizens expect their lives to get better. Emigration is determined by economic, socio-cultural, political, psychological, security, geographical, population / demographic, and other factors. More often than not, emigration occurs due to the economic factors. Notwithstanding that economic indicators such as GDP per capita and monthly wages improved in 2013-2017, the number of emigrants still increased. One of the priorities of national security policy is to strengthen social security and improve a demographic situation; in order to realize it one must stimulate return emigration. However, the number of both returning Lithuanian citizens and young people aged 20-24 is declining annually. This shows how the indicator of return emigration to Lithuania is becoming worse and how ineffective the strategy of encouraging return emigration is.

\section{Method of Research}

This study is predicated on qualitative and quantitative data analysis research, which comprises the following: the analysis of the various sources of literature which creates a theoretical framework for interrelatedness of emigration and national security; the documentary analysis which reviews relevant legislation; the statistical analysis which is conducted to search for correlation among the number of emigrants and the pool of economic data; the quantitative research which is performed to evaluate the emigrants' attitudes toward national security; and the comparison and summary of theoretical and practical aspects of national security. The questionnaire survey was applied as quantitative research method. The questionnaire contains closed-ended questions. The sample of the study is 250 emigrants. A total of $74 \%$ of all questionnaires were completed. The final number of the examined questionnaires was 185 . The method of selection was that of probability sampling; the questionnaire was distributed through online channels. An available tool is a questionnaire consisting of five sets of questions. After having analyzed the literature of Lithuanian and foreign authors on the impact of emigration on national security, the research questions were formulated.

The respondents' sample characteristics. The majority of survey respondents are women, constituting $67 \%$. The number of those surveyed, aged $26-35$, is $34 \%$. And a substantial part of respondents is $36-45$ years old, making up 31\%; 46-55 years old, 18\%; 18-25 years old, 11\%; and 56 years old and more, $6 \%$. The distribution of the majority of respondents corresponds to the number of emigrated Lithuanian citizens by age. In 2018, a bigger number of citizens emigrated at the age of 20-24, 25-29, 30-34. [12]. The largest share of respondents is employed people, comprising $83 \%$; working students, $3 \%$; unemployed people, $2 \%$; students, $1 \%$; and others, $10 \%$. The majority of the surveyed are those with a higher education. Most respondents have non-university higher education diplomas, constituting $31 \%$; higher university (bachelor's degree) education diplomas - 25\%; higher university (master's degree) education diplomas $-19 \%$; secondary education certificates $-21 \%$; incomplete secondary education certificates $-2 \%$; and those with a postdoctoral degree $-1 \%$. The majority of survey respondents emigrated to Germany and make up $51 \%$; to Norway $-14 \%$; to the UK - $11 \%$; to Spain - 4\%; to the Czech Republic - 4\%; to the Netherlands, Denmark - 3\%; to Slovenia, Japan, Switzerland, Andorra, and Poland - 1\%. Although the survey included the majority of those emigrated to Germany, more Lithuanians emigrate to the UK, hence making up 62\%, and then to Germany and Norway $-9 \%$, respectively. It is observed that $65 \%$ of those emigrated to Germany have non-university higher education diplomas, and $23 \%$ of survey respondents have a university degree. The assumption is that their education determines their active participation in the survey.

\section{Research Results}

Long-term emigration lasting longer than a year [2] exerts a considerable influence on the country, for a large number of long-term emigrants do not return. This is confirmed by the data revealing that the highest number of emigrants have been living abroad for ten or longer years (see Figure 3). Short-term emigration, that is, 6\% of those living abroad for less than one year (see Figure 3), can be qualified as a search for temporary financial improvement. It is mainly reflected in the event of a financial crisis wherein one can observe the loss of new jobs, see how emigration contributes significantly to searching for personal income and obtaining new experiences abroad. A substantial body of survey respondents (94\%) identify themselves as long-term emigrants, and $76 \%$ of them have a higher education. It refers to the loss of educational investment and qualified labor force. 


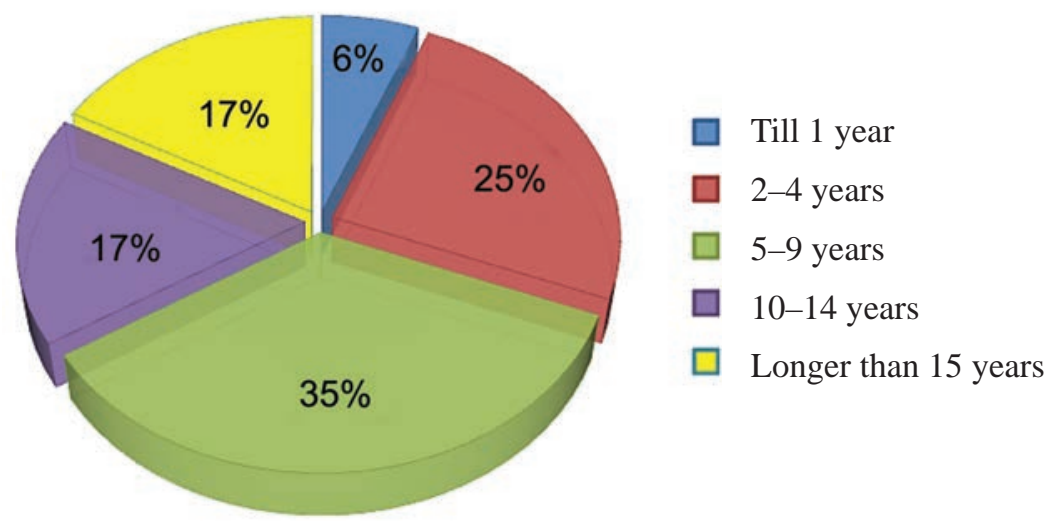

Fig 3. Emigration duration for the emigrants from Lithuania.

Source: Lithuanian Department of Statistics, 2018.

The majority of emigrants left their homeland approximately five to nine years ago - one attributes this period to the financial crisis that occurred in Lithuania in 2009 - and the largest number of emigrants was recorded in 2010. Many Lithuanian people emigrated roughly for two to four years; the period of their departure can be closely related with introduction of a single European currency, the euro, in 2015, because after its introduction the number of emigrants increased rapidly in 2016-2017. [11].

Most friends / relatives live abroad

Willingness to test oneself, to gain new experience

Desire to obtain foreign citizenship

Better living conditions abroad

Social security is not properly guaranteed in Lithuania guarantees (pension, health care, etc.)

Poor education system

Instability of the political situation

It is difficult to get /or pay a loan

High house prices in Lithuania

High level of corruption in Lithuania

Excessive workload, low quality work equipment in Lithuania

Adverse professional development and/or career advancement opportunities in Lithuania

It is difficult to find a well-paid job by specialty in Lithuania

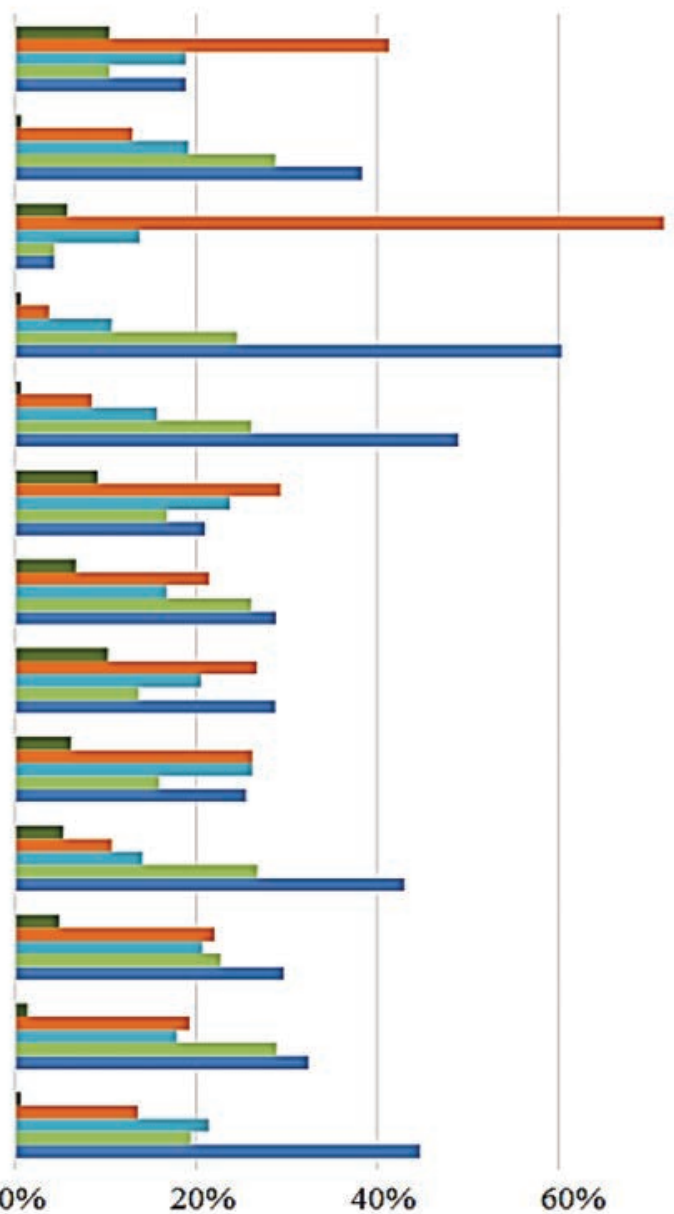

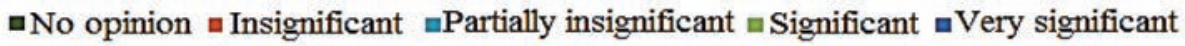

Fig 4. The reasons for emigration.

Source: compiled by authors 
The data obtained show that the main reasons for deciding to emigrate are as follows: better living conditions abroad; social guarantees which are not properly ensured in Lithuania; difficulties in finding a well-paid job by specialty in Lithuania; and a high level of corruption in Lithuania.

There is a tendency for similar answers to the question depending on the age of the respondents, as well as on the country of emigration. The majority of emigrants, aged 26-35 and 36-45, most often mentioned that their decision to emigrate was influenced by searching for better living conditions abroad, by finding it hard to find a well-paid job by specialty in Lithuania, by obtaining or paying a loan, and by having high house prices in Lithuania. On the other hand, those belonging to the age groups of 46-55 years and 56 years and older also mentioned better living conditions, but more accentuated the fact that the majority of their friends / relatives live abroad, that there is excessive workload and poor working conditions, and that there exist insufficient social guarantees in Lithuania and a high level of corruption along with an unstable political system. The youngest emigrants aged 18-25 highly emphasized the desire to try out their skills and gain valuable experiences; also, they point out unfavorable professional development or career advancement opportunities and a poor education system. Those who emigrated to Germany mostly highlighted both economic and political reasons for their decision to emigrate - that is, better living conditions, difficulties in finding a well-paid job by specialty in Lithuania, and high levels of corruption alongside an unstable political system. Meanwhile, those who emigrated to the UK and Norway mainly referred to the economic reasons: better living conditions, difficulties in finding a well-paid job by specialty in Lithuania, unsecured social guarantees, high house prices, and difficulties in getting or paying a loan.

The study revealed that the main motives - indicated by the respondents aged 26-45 - for emigration are economic ones, that is, better living conditions, higher monthly wages, high house prices, difficulties in paying a loan. The youngest people at the age of 18-25 and more emphasized the psychological reasons for emigrating - the desire to try out their skills; gaining new experiences; a poor education system. Those who are 46 years old and older more emphasized both political and psychological reasons for emigrating: most friends and relatives live abroad, high levels of corruption, and political instability.

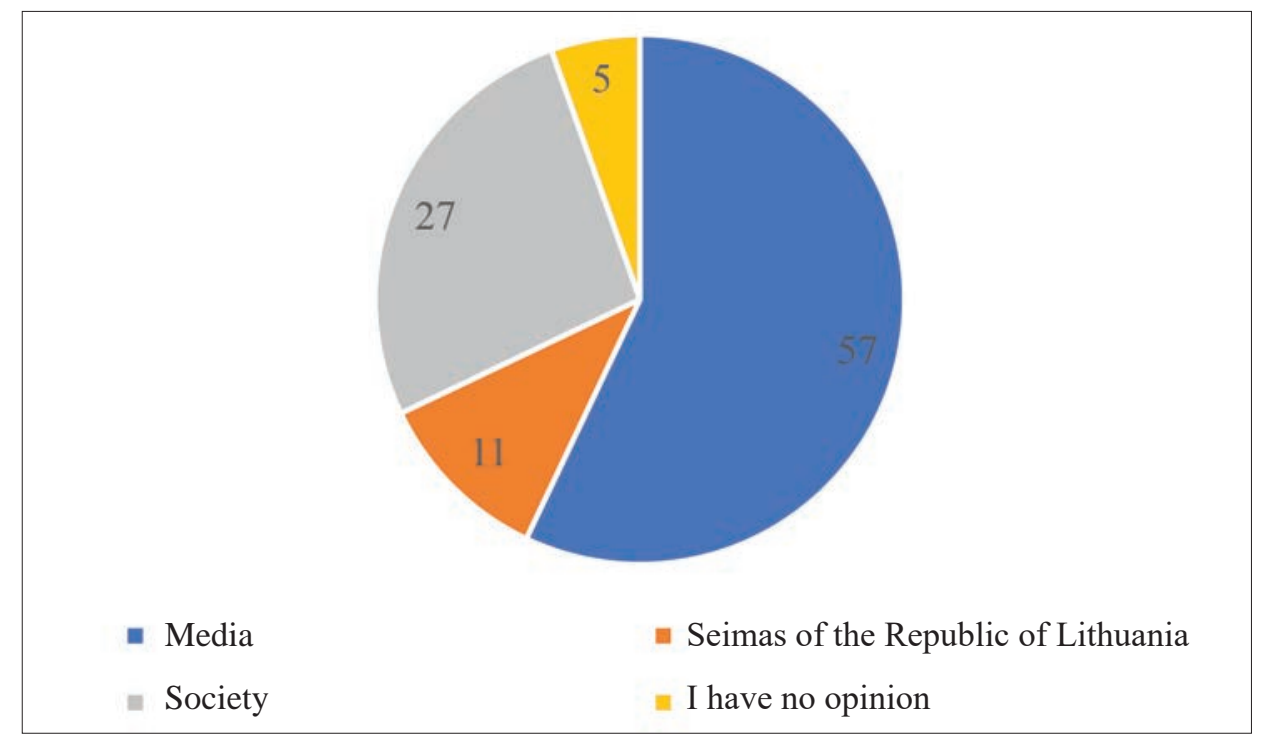

Fig 5. The respondents' opinions on the formation of attitudes toward emigrants and emigration in percentage. Source: compiled by authors

Figure 5 shows that the media is treated as the most effective tool in forming the attitudes toward emigrants and emigration by $57 \%$ of survey respondents; the society, $27 \%$; and the Seimas of the Republic of Lithuania, 11\%.

More than half of those surveyed believe that the media is key to forming the attitudes toward emigrants and emigration. Whilst representing emigration, the negative facets of Lithuanian social, economic, political, and other domains are mostly emphasized. 


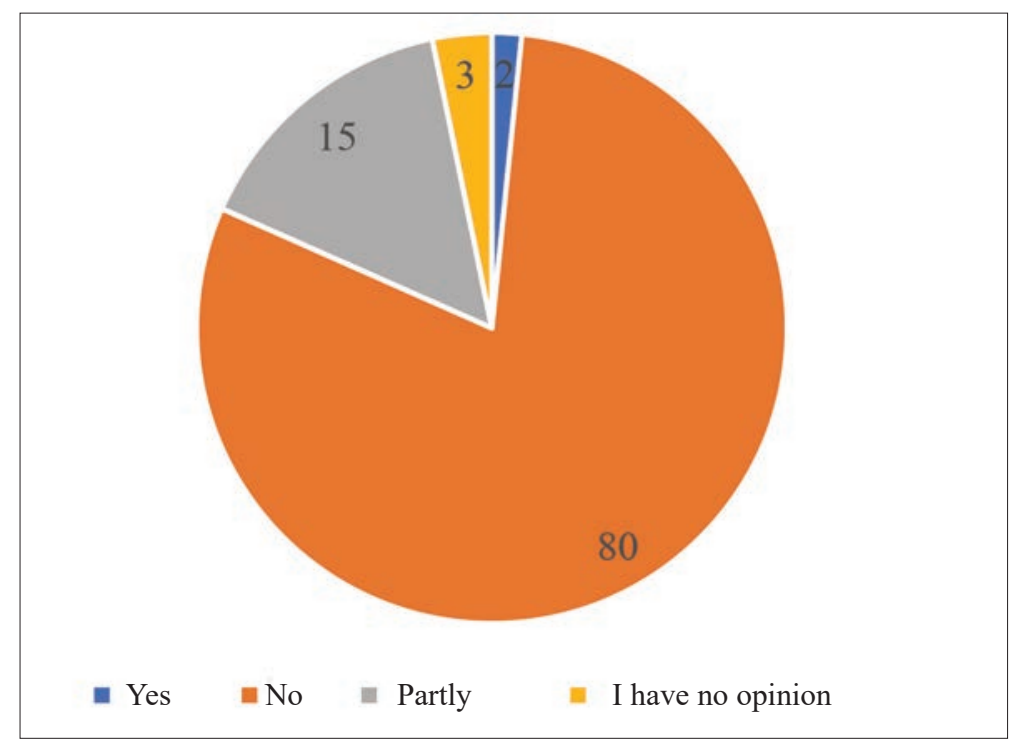

Fig 6. What respondents think of the state's efforts to stimulate return emigration in percentage.

Source: compiled by authors

Investigating whether respondents see any state's efforts to encourage return emigration, it became clear (see Figure 6 ) that $80 \%$ of them do not see any; $15 \%$ of them see some made by the state; and $2 \%$ of them see the state's endeavors to incentivize return emigration. The indicator of return emigration to Lithuania is getting worse, and the data presented by the Lithuanian Department of Statistics reveal ineffectiveness of the strategy for promoting return emigration. In the period 2014-2017, the number of returning citizens decreased by nine thousand. [12]. Only in 2018 can one see that a relatively large number of returning emigrants increased by 6.5 thousand during the year; 16.5 thousand emigrants - the majority of whom emigrated to the UK at the age of 24-29 aged - in total returned to Lithuania. [12].

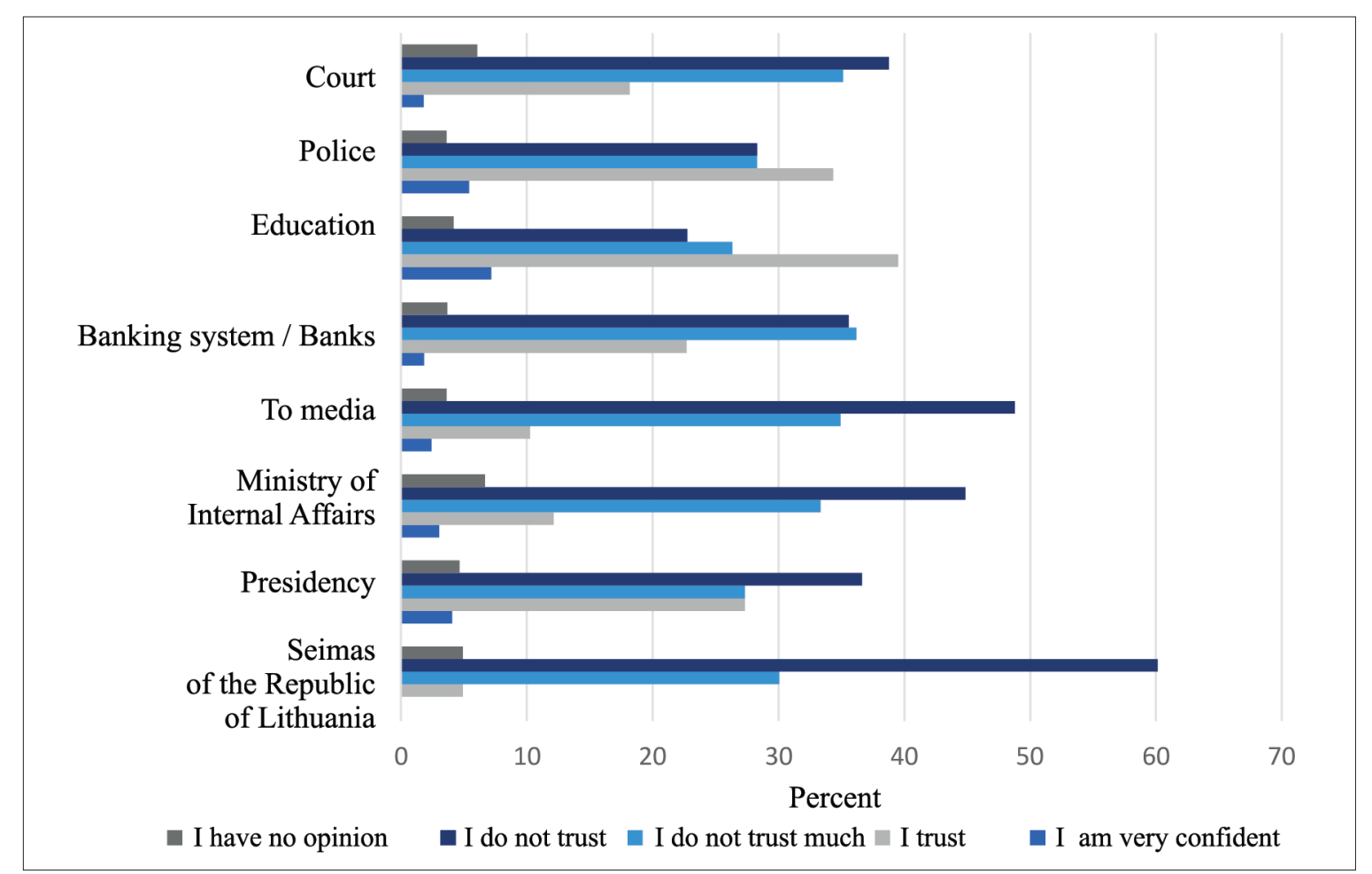

Fig 7. The respondents' evaluation of the most trusted Lithuanian institutions in percentage. Source: compiled by authors 
Figure 7 shows which Lithuanian institutions respondents trust the most. There is a similar-answers-to-thequestion tendency by age and countries to which they emigrated. Younger people aged 18-35 emphasized that the most untrusted institutions are the Seimas of the Republic of Lithuania, the media, and the police. Thirty-six-year-old people and older also stressed that they do not trust the Seimas of the Republic of Lithuania, the Ministry of the Interior, the court, the Executive Office of the President, and the banking system. Those who emigrated to Germany have the greatest distrust of the Seimas of the Republic of Lithuania and the media; to the UK - the police, the court, the Ministry of the Interior; to Norway - the Seimas of the Republic of Lithuania, the Executive Office of the President, the court. It appears that respondents do not trust the main authorities. In order to strengthen Lithuania's national security, citizens must be ingenuously involved in its management, and there must operate a trusted system of their communities and organizations, legislative, executive, and other institutions. However, in order for citizens to cooperate with a view to consolidating Lithuania's national security, the trust people put in the authorities is indispensable.

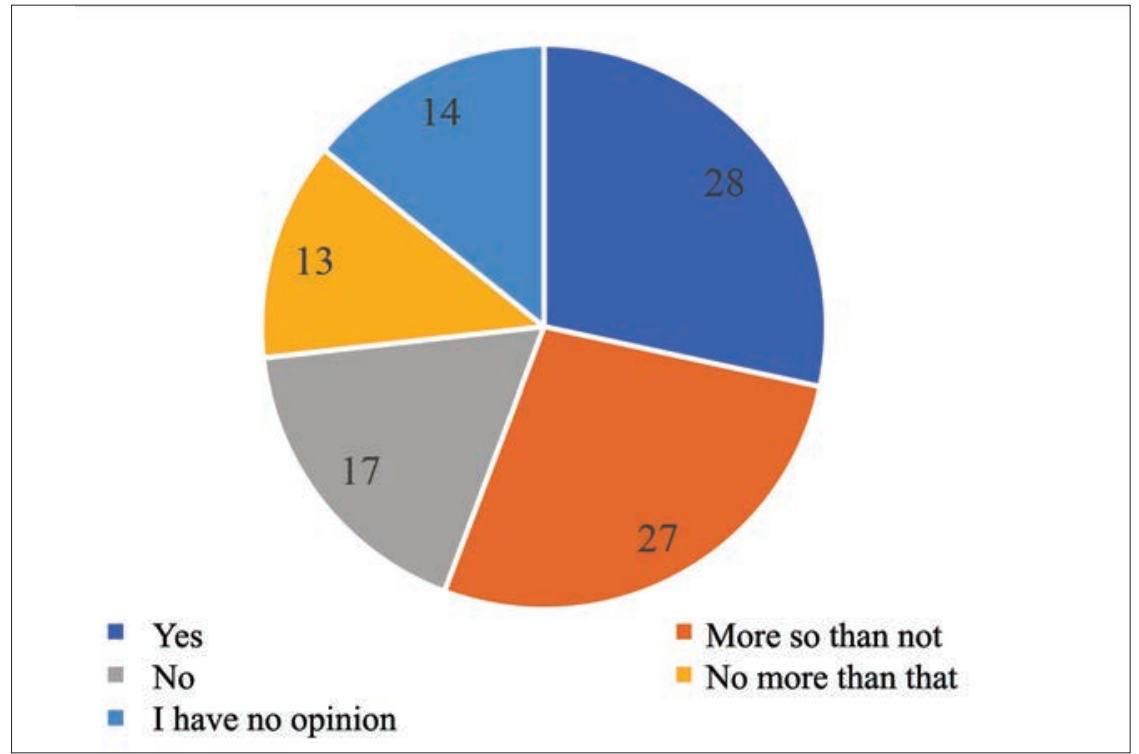

Fig 8. The respondents' credence to the Lithuanian Armed Forces in percentage.

Source: compiled by authors

The survey revealed to what extent respondents lend credence to the Lithuanian Armed Forces. The majority of respondents trust the Lithuanian Armed Forces, constituting 28\%; a very similar part of respondents trusts more than they do not trust $-27 \%$; those who do not trust $-17 \%$; and those who do not trust more than they trust $-13 \%$. In 2018, according to the data of the Lithuanian Department of Statistics, as many as $71 \%$ of citizens put trust in the Lithuanian Armed Forces. Conducted by Vilmorus [19], the survey disclosed that $60.3 \%$ of citizens lent credence to the Lithuanian Armed Forces which was placed in the third position of the most trusted public institutions of all.

The majority of respondents think that a threat is not growing, making up 46\%; those who think it is growing constitute $33 \%$. One-third of respondents believe that a threat is not growing, and about half of respondents believe that it is growing. However, in 2012, the survey was performed according to which the majority of the population (60.1\%) still held the opinion that there were no threats posed to Lithuania, and only $18 \%$ of respondents thought that Russia was still a threat. Conducted in 2006 , the study showed that $54.5 \%$ of the population was convinced that Russia represented a real threat to Lithuania's independence, and only part of respondents were of the opinion that a threat emerged recently; others thought we had problems concerning the said situation.

It is probable that the further from the environment under evaluation the individual is located, the more a sense of security is associated with imaginary threats which are communicated through the media [5]. It can be assumed that when evaluating a security situation in Lithuania, the European Union, and the world, people are prone to think about those topics which are familiar to them and are often escalated in the media, such as military conflicts, political instability, terrorist attacks or refugee crisis. Such selective assimilation of information can give an impression of how relatively safe in our country in comparison to other countries it is. 


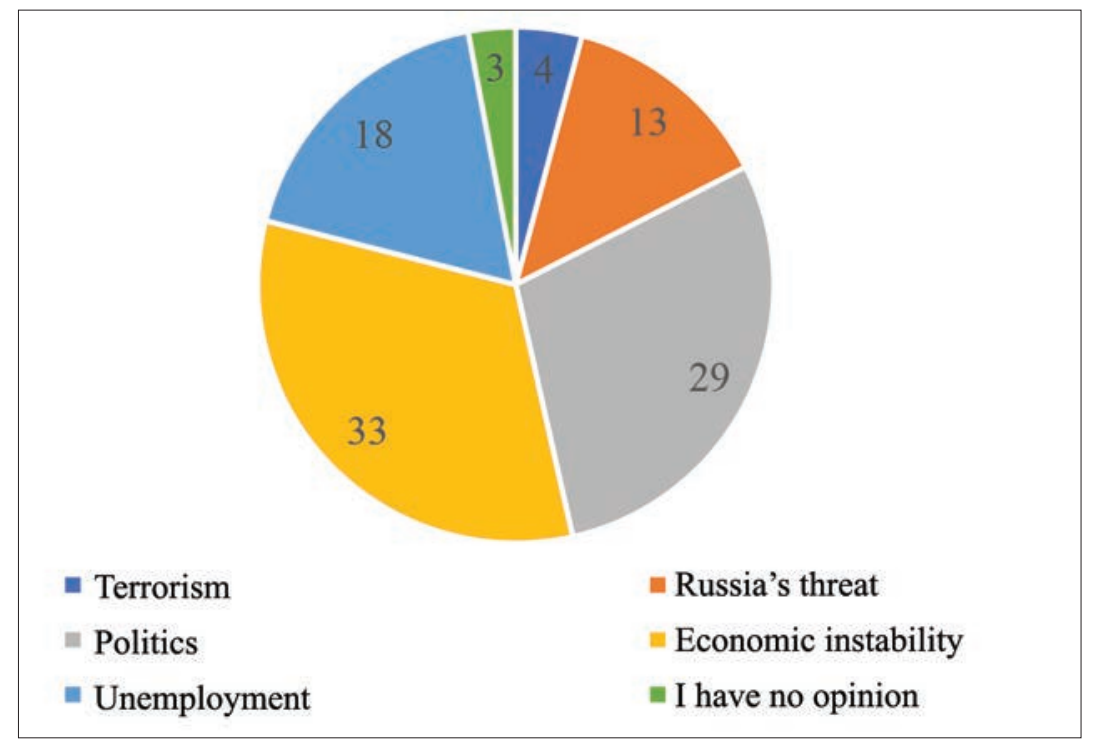

Fig 9. The respondents' opinions on the greatest threat to Lithuania's national security in percentage.

Source: compiled by authors

Figure 9 shows, according to the respondents, what represents the biggest threat to Lithuania's national security. Thirty-three percent of those surveyed believe that it has to do with economic instability; $29 \%$ of them with politics; $18 \%$ of them with unemployment; $13 \%$ of them with the threat posed by Russia; and $4 \%$ of them with terrorism. As mentioned earlier, the main reasons why the respondents emigrated are economic ones which are key to their answer to the question about the most serious threat to Lithuania's national security. Also, the respondents previously indicated that they did not trust the Seimas of the Republic of Lithuania the most; and this answer seems to be interrelated, because a large part of the respondents treated politics as a threat.

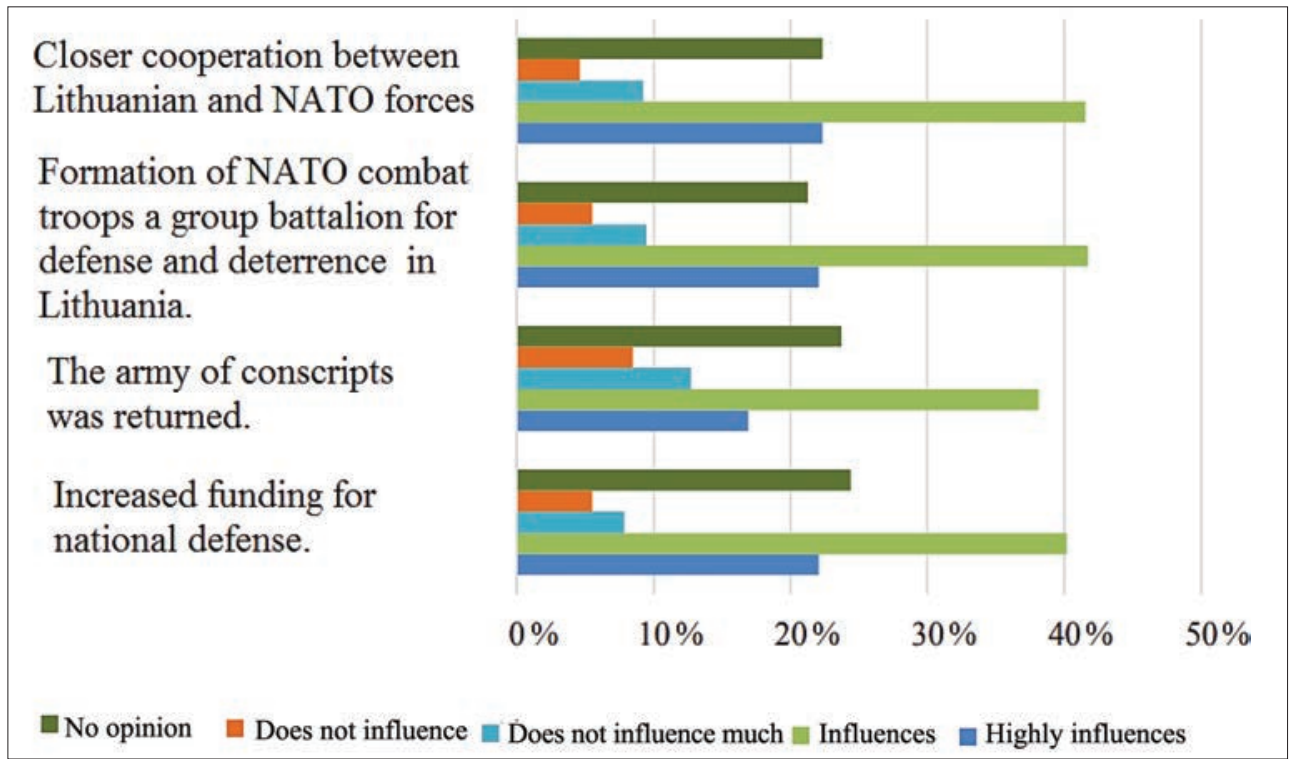

Fig 10. The respondents' opinions on what affects Lithuania's national security.

Source: compiled by authors

Finally, this survey shows that economic instability and politics represent the greatest threat to Lithuania's national security (see Figure 3). Also, the surveyed - whose views on the North Atlantic Treaty Organization (NATO) were evaluated - state that NATO forces play a role. The prevailing view is that NATO forces are important to Lithuania, and without a defensive partner the Lithuanian Armed Forces are not capable of defending the state. 


\section{Conclusions}

Large-scale emigration is an internal risk determinant, danger, and threat to national security to which one must draw considerable attention owing to the declining general and especially working-age population, the loss of taxpayers and qualified specialists, the weakening of the emigrants' relations with their homeland, the gap between citizens and political processes occurring in Lithuania, and the inability to actively participate in the political life of the country. One of the priorities of national security policy is to consolidate social security, improve the demographic situation; to realize the said, one must urge return emigration. Also, a large part of emigrants do not plan to return to Lithuania (44\%).

After having analyzed the reasons of emigration, it can be concluded that the decision to emigrate is determined by various factors, mainly the economic ones. The respondents aged 18-25 emphasized the psychological reasons for emigrating which are associated with their desire to try out their skills, with gaining new experiences, as well as with a poor education system. Those who are over the age of 46 point out political and psychological reasons of emigration: friends and relatives live abroad; a high level of corruption; and political instability. One of the tasks of national security policy is to promote return emigration. Eighty percent of the surveyed do not see such encouragement.

Long-term emigration lasting longer than a year exerts a bigger impact on the country as most of long-term emigrants do not return. The data show that emigrants live abroad for ten or longer years. Short-term (lasting less than a year) emigration can be qualified as a search for temporary financial improvement. It becomes obvious in the event of a financial collapse during which people may lose their jobs, and emigration determines the need to search for personal income and gain new experiences abroad.

Most of the surveyed (94\%) identify themselves as long-term emigrants, and $76 \%$ of them have a higher education. It points to the loss of educational investment and qualified labor force.

Evaluating the role of the North Atlantic Treaty Organization (NATO) in the domain of Lithuanian national security, respondents answered that the role of NATO forces is of great importance, that NATO forces are an important defense partner of Lithuania, and that without NATO support the Lithuanian Armed Forces are not able to defend the state. The results of the research disclose the threat emigration represents to Lithuania's national security.

\section{References}

1. A. Ažubalis, Aktualios Lietuvos ugdymo sistemos raidos po 1990 m. problemos ir siūlomi jų sprendimo būdai. Globalizacijos iššūkiai ugdymo procesui: visuomenė ir kariuomenè. Vilnius: Generolo Jono Žemaičio Lietuvos karo akademija, 2013.

2. Butkus, M., Matuzevičiūtė, K., Emigracijos ir reemigracijos situacija Lietuvoje. Vadyba, 14 (1). Lietuvos verso kolegija, 2009.

3. A. Damulienè, Migracijos problema Lietuvoje ir jos įtaka šalies ekonomikai. Business systems and Economics. Vol. 3. Vilnius: Mykolo Romerio universitetas, 2013.

4. I. Gečienė, Lietuvos gyventojų subjektyvus saugumo suvokimas išorinių grèsmių kontekste. Kultūra ir visuomenė socialinių tyrimų žurnalas. Nr. 6 (1). Kaunas: Vytauto Didžiojo universitetas, 2015.

5. Janušauskienė, D., Vileikienė, E., Nevinskaitė, L., Gečienè-Janulionė, I. Ar Lietuvos gyventojai jaučiasi saugūs? Subjektyvus saugumas kintančiame geopolitiniame kontektste. Vilnius: Lietuvos socialinių tyrimų centras, 2017.

6. Jurènienė, V., Bleizgytė, L., Kultūros svarba užtikrinant valstybės saugumą. Visuomenės saugumas ir viešoji tvarka. Nr. 18. Vilnius: Mykolo Romerio universitetas, 2017.

7. J. Kirshner, Globalization and National security. Politics \& International Relations. New York: Routledge, 2013.

8. G. Lazaridis, Security, Insecurity and Migration in Europe. Research in Migration and Ethnic Relations Series. New York: Routledge, 2016.

9. Lietuvos Respublikos seimo nutarimas dẻl nacionalinio saugumo strategijos patvirtinimo, 2002 m. gegužès 28 d. Nr. IX-907. [Online] Available: https://www.e-tar.lt/portal/lt/legalAct/TAR.2627131DA3D2/LLwfQepmnD

10. Lietuvos Respublikos Nacionalinio saugumo pagrindų įstatymas, 1996 m. gruodžio 19 d. Nr. VIII-49. [Online] Available: https://e-seimas.lrs.lt/portal/legalAct/lt/TAD/TAIS.34169/asr

11. Lietuvos Statistikos departamentas, 2017. [Online] Available: https://osp.stat.gov.lt/services-portlet/pub-editionfile? $\mathrm{id}=26780$

12. Lietuvos Statistikos departamentas, 2018. [Online] Available: https://osp.stat.gov.lt/services-portlet/pub-editionfile? id $=30020$

13. Maslauskaitė, A., Stankūnienė, V., Šeima abipus sienų. Lietuvos transnacionalinės šeimos genezė, funkcijos, raidos perspektyvos. Vilnius: Tarptautinè migracijos organizacija (TMO), 2007.

14. E. Matulionytė, Grèsmių nacionaliniam saugumui nustatymas ir jų prevencijos galimybès. Mokslo darbai. 
Jurisprudencija. Nr. 4(106). Vilnius: Mykolo Romerio universitetas, 2008.

15. E. Nabažaitė, Emigracijos diskurso rèminimas Lietuvos interneto dienraščiuose. Informacijos mokslai. Nr. 78. Vilnius: Vilniaus universiteto leidykla, 2017.

16. Nacionalinio saugumo strategija, 2017. [Online] Available: https:/www.e-tar.lt/portal/lt/legalAct/ TAR.2627131DA3D2/asr

17. I. Naulickaitė, I.., Melnikas, B. Emigracija ir globalizacijos procesai: iššūkiai, šiuolaikinès tendencijos, problemos, sprendimai. Mokslas - Lietuvos ateitis. Verslas XXI amžiuje. Nr. 8 (2)Vilnius: Vilniaus Gedimino technikos universitetas, 2016.

18. Petrauskaitè, A.; Kazlauskaitè Markelienė, R.; Gedminienè, R. Šalies saugumas ir gynyba. Metodinè medžiaga Lietuvos bendrojo lavinimo mokyklų mokytojams. Vilnius: Generolo Jono Žemaičio Lietuvos karo akademija, 2016.

19. Vilmorus (2019). Pasitikejjimas institucijomis. [Online] Available: http://www.vilmorus.lt/index. php? mact $=$ News, cntnt01, detail,0\&cntnt01 articleid $=2 \&$ cntnt01 returnid $=20$

20. P. D. Williams, ed. Security Studies: An Introduction. Oxon, New York: Routledge, 2013. 